\title{
Equipping tomorrow's historical ecologist: priorities for documenting conditions of the terrestrial fauna of Santa Cruz Island, California
}

\author{
Christina L. Boser ${ }^{1, *}$, T. Scott Sillett ${ }^{2}$, Paul W. Collins $^{3}$, Kathryn R. Faulkner $^{4} \dagger$, \\ W. Chris Funk ${ }^{5,7}$, Cameron K. Ghalambor ${ }^{5}$, Lyndal Laughrin ${ }^{6}$, Gregory B. Pauly ${ }^{7,8}$, \\ Jeanne M. Robertson 7,8, Robyn SheA $^{9}$, And Winston Vickers 10 \\ 1 The Nature Conservancy, Ventura, CA 93001 \\ ${ }^{2}$ Migratory Bird Center, Smithsonian Conservation Biology Institute, National Zoological Park, Washington, DC 20013 \\ ${ }^{3}$ Santa Barbara Museum of Natural History, Santa Barbara, CA 93105 \\ ${ }^{4}$ United States National Park Service, Ventura, CA 93001 \\ ${ }^{5}$ Department of Biology, Graduate Degree Program in Ecology, Colorado State University, Fort Collins, CO 80523 \\ ${ }^{6}$ University of California Natural Reserve System, UCSB, Santa Barbara, CA 93106 \\ ${ }^{7}$ Natural History Museum of Los Angeles County, Los Angeles, CA 90007 \\ ${ }^{8}$ Department of Biology, California State University Northridge, Northridge, CA 91220 \\ ${ }^{9}$ California State University Channel Islands, Camarillo, CA 93012 \\ ${ }^{10}$ The Institute for Wildlife Studies, Arcadia, CA 90704
}

\begin{abstract}
Historical ecological research provides valuable insights for contemporary conservation management. Gaps in historical records, however, can limit the utility of that research. Future conservationists may therefore find themselves disadvantaged by the current societal trend of underinvestment in systematic collection of museum specimens and natural history information. To reduce that risk, we asked what managers and scientists could do today to better document the past and present conditions of Santa Cruz Island, California, as a means to improve both contemporary and future conservation. We focused our inquiry on the island's terrestrial fauna, which includes numerous taxa of conservation concern. Here we present recommendations for research and collection that will enhance not only the understanding of past and present ecological conditions on the island but also the records that will be accessible to future historical ecologists.
\end{abstract}

RESUMEN.—La investigación ecológica histórica proporciona datos de gran utilidad para la gestión de la conservación contemporánea. Sin embargo, las lagunas en los registros históricos, pueden limitar la utilidad de dicha investigación. Por lo tanto, los futuros conservacionistas pueden verse en desventaja, por la actual tendencia social de insuficiente inversión para la recopilación sistemática de especímenes para museos y por la escasa información sobre su historia natural. Con el propósito de reducir este riesgo, nos preguntamos qué pueden hacer hoy en día los gestores y científicos para documentar las condiciones pasadas y presentes de la Isla Santa Cruz, California, como un medio para mejorar tanto la conservación actual como la futura. Centramos nuestra investigación en la fauna terrestre de la isla, que incluye numerosos taxones de interés para la conservación. Aquí presentamos recomendaciones para la investigación y la recopilación, que mejorarán no sólo la comprensión de las condiciones ecológicas pasadas y presentes en la isla, sino también el acceso a los registros para futuros ecólogos históricos.

Conservation management is often improved by an understanding of historical ecology-how current environmental conditions have been shaped by past conditions and interactions between humans and their environment (Rick and Lockwood 2013, Szabó
2015). To accrue that benefit, however, historical ecologists need sufficient records from the past. Unfortunately, recent decades have seen declining investments in systematic collections and surveys (Suarez and Tsutsui 2004). Thus future historical ecologists may lack the

\footnotetext{
*Corresponding author: cboser@tnc.org
} $\dagger$ Retired

TSS (1) orcid.org/0000-0002-7486-0076

CKG (D) orcid.org/0000-0003-2515-4981
PWC GBP orcid.org/0000-0002-9271-6561 orcid.org/0000-0002-2381-2576
$\mathrm{KRF}$

RS (1D orcidorg/0000-0003-2738-9581 
data they need to understand our present, an era of extraordinary environmental change (Brodersen and Seehausen 2014, Holmes et al. 2016). To prepare future historical ecologists and conservation managers for success, contemporary managers and scientists should consider what they can do to ensure that a sufficient record of current conditions is archived for future use (Morrison et al. 2017).

The California Channel Islands provide an illuminating case study of applying historical ecology to conservation planning and management (Rick et al. 2014, Morrison et al. 2018). The islands are globally renowned for their unique ecosystems, endemic species, evidence of early humans in North America, and conservation importance. They also provide a living laboratory for studying how humans have shaped biodiversity (Rick et al. 2014). Yet systematic cataloging of the archipelago's natural resources did not begin until the late 1800 s, after the islands had undergone substantial ecological change from livestock ranching. Some taxa and resources have been relatively well studied over the intervening decades, but for most taxa, data and specimen records are temporally and spatially spotty at best. Identifying and addressing such gaps has the potential to improve conservation decision making today and to provide an invaluable legacy for future scientists and land managers.

To discuss this issue, conservation managers and researchers convened in Santa Barbara, California, in January 2016 to identify and describe the data sets and types of specimens that should be prioritized for collection based on their expected value to current and succeeding generations of conservation managers. Participants had expertise in island ecosystems and biodiversity, conservation management, conservation genetics, and the interplay of cultural and natural histories. The workshop aimed to examine Santa Cruz Island as a model system for this type of "future historical ecology" inquiry (Morrison et al. 2018). Here we present results from the workshop in which the research and conservation of terrestrial animals were discussed.

\section{Focal Area and Resources}

Santa Cruz Island is the largest and most biologically diverse of the California Channel Islands (Schoenherr et al. 1999). The $250-\mathrm{km}^{2}$ island is physically defined by 2 mountain ranges running from east to west divided by a central valley. On south-facing slopes, coastal sage-scrub dominates; north-facing slopes are characterized by chaparral, oak woodland, and pine forests. Santa Cruz Island is home to at least 52 breeding bird species, of which 8 are endemic taxa; 4 endemic mammals; 8 reptiles and amphibians, of which at least 3 are endemic taxa; a minimum of 2 breeding bat species; and nearly 1000 invertebrates including at least 15 endemic species (Rentz and Weissman 1981, Miller 1985, Powell 1994, Schoenherr et al. 1999, Chatzimanolis and Caterino 2011, Rick et al. 2012, Collins and Jones 2016).

The ecosystem of Santa Cruz Island has been shaped by humans for millennia (Erlandson et al. 2011, Rick et al. 2014, 2018). For at least 13,000 years, native islanders altered their environment with fire, hunting, and species translocation. Dramatic changes occurred early in the 19th century when indigenous populations were displaced by settlers of European descent who engaged in commercial agricultural enterprises and the hunting of marine mammals. Ranchers introduced large populations of livestock and other nonnative animals to the landscape over a period of several decades, leading to rapid and unprecedented levels of soil erosion and vegetation loss (Brumbaugh 1980, Pinter and Vestal 2005). Conservation management of Santa Cruz Island began in 1978 when The Nature Conservancy acquired the majority of the island. Channel Islands National Park was established in 1980.

Removing nonnative animals and prioritizing the recovery of imperiled species and ecological processes on Santa Cruz Island have been the primary goals of ongoing land management (Rick et al. 2014, NPS 2015). The island has experienced rapid ecological change in response to livestock removal (Klinger et al. 2002, Morrison 2011, Beltran et al. 2014). Most active management since the elimination of nonnative ungulates has focused on eradicating Argentine ants (Linepithema humile) and a suite of invasive plant species (Cory and Knapp 2014) as well as recovering imperiled animal species like the island fox (Urocyon littoralis) and Bald Eagle (Haliaeetus leucocephalus) (Coonan et al. 2010).

For the purposes of this inquiry, we assume that the land owners and their primary mission 
of resource conservation will remain the same in the coming decades. However, we did consider that these organizations may reprioritize conservation targets due to changing conditions on the islands and mainland. For example, the coming decades are predicted to be warmer and drier in Southern California, with droughts becoming more severe (Hayhoe et al. 2004, Cayan et al. 2008, Diffenbaugh et al. 2015). Climate change may affect vegetation recovery and the invasion dynamics of nonnative plants (Randall et al. 2018). We therefore considered that environmental conditions on Santa Cruz Island may become increasingly novel, rendering past or current conditions unsuitable as future management targets. Meanwhile human population pressure and development on the mainland may increase societal reliance on the islands to provide the refugia for once widespread but increasingly vulnerable and degraded natural coastal communities of Southern California. To improve the ability of conservation managers to make science-based resource management decisions in that future, a concerted effort is needed to document the island's past and present conditions.

\section{Documenting the Past}

We recognized that our ability to identify and secure information about past conditions of the island may be much greater than that of future generations, so we assessed priorities for documenting past faunal conditions. To spur that inquiry and prioritization, we considered how we might use such information for conservation management today. We reviewed several initiatives that are under way to catalog historic data sets and to increase data discoverability. For example, the California Islands Biodiversity Information System (Cal IBIS) is aimed at organizing and increasing accessibility to records of vouchered island species and observational field data. This information system-based on the symbiota.org platform-will generate species lists for defined geographies and facilitate the tracking of species distributions over time. Additionally, a database of published and unpublished literature, housed and funded by the University of California Reserve System in cooperation with the National Park Service and The Nature Conservancy, holds over 2000 entries on biological and cultural collections of Santa Cruz Island.

We also emphasized the importance of genomic and demographic research on ecologically important species. For example, intensive research and monitoring efforts focused on populations of endemic island fox and spotted skunk (Spilogale gracilis amphiala) since 2000 have resulted in a sizable collection of biological samples (e.g., blood, full carcasses) archived at the California Animal Health and Food Safety Laboratory of the University of California, Davis, and at the Santa Barbara Museum of Natural History. DNA from these and other historically collected specimens has been used to estimate the island fox's date of arrival on the island chain (Hofman et al. 2015). As molecular technologies continue to advance, future researchers may use these samples to investigate an even greater array of questions about the origin, evolution, and conservation relevance of this species.

Numerous temporal, taxonomic, spatial, and demographic gaps remain in available data about Santa Cruz Island. In contrast to the relatively substantial and consistent collection of carnivores and invertebrates, the collection of herpetofauna and birds has decreased significantly in recent decades. Collection of the endemic Island Scrub-Jay (Aphelocoma insularis), for example, declined from approximately 100 specimens each decade between 1890 and 1910 to fewer than 10 each decade in 1990-2010 (Collins 2009). This represents a loss of valuable information on the bird's evolutionary response to change during the 20th century. Many island taxa have demonstrated rapid morphological evolution or fine-scale morphological and genetic variation (Millien 2006, Van Vuren and Bakker 2009, Langin et al. 2015), underscoring the value of consistent and systematic specimen collection. This is especially pertinent given the rapid changes to island vegetation over the past 150 years due to intensive herbivory by livestock and then the release from grazing pressure following removal of those ungulates.

The usefulness of some collections, especially of invertebrates, is limited because many specimens have not been fully identified, photographed, or recorded in digital databases. Insect specimens from Santa Cruz Island are generally well represented in the collections of many California museums, yet 
most of these specimens are not identified to the species level (SDNHM 2012). Efforts to identify and digitize historic specimens will fill data gaps in our understanding of the diversity and abundance of invertebrate communities. For instance, a recent inventory of ant collections from the California Channel Islands uncovered a species, Camponotus dumetorum, new to Santa Cruz Island. This specimen was collected in 1913 and deposited at the Natural History Museum of Los Angeles County. An ongoing intensive survey of ants on Santa Cruz Island has not detected this species, which raises the question of whether it is still present on the island or extirpated because of the extensive loss of woody chaparral vegetation in the early 1900 s.

We recommend that island scientists and managers prioritize research designed to document past faunal conditions and to elucidate mechanisms and rates of species colonization, expansion, and extinction. This could be accomplished by identifying, photographing, and digitizing existing collection data including specimen records, field notes, survey data, and nontraditional data sources such as images. Modeling the historical occurrence and abundance of key species including vertebrates and ecologically important invertebrates such as Hymenoptera, Lepidoptera, and Coleoptera would also be useful and could be used to map the likely distribution of preranching vegetation types. These data would also help to develop hypotheses about the distribution and abundance of animal species of management concern and their habitats prior to European settlement of Santa Cruz Island. Restoration efforts may be biased when management targets are only based on recent population data which may reflect population sizes and demographic structures highly influenced by unnatural conditions such as invasive species introductions or recent weather patterns. This "shifting baseline" in which each generation views recent conditions as original conditions affects the interpretation of contemporary ecosystems and can result in inappropriate management goals (Pauly 1995, Jackson et al. 2001). Moreover, basing restoration goals on remnant vegetation patterns and densities overlooks historical information on population structure and variability under local environmental conditions, particularly for habitats defined by long-lived plant species.
An investigation of historical data will improve our ability to understand baseline conditions on Santa Cruz Island, as well as long-term trajectories.

Reconstructing early- to mid-19th century faunal conditions will be a challenging multidisciplinary effort. The research community has outlined hypotheses about the preranching distributions of vegetation types on the northern Channel Islands (e.g., Kindsvater 2006). These hypotheses do not explicitly account for soil types and island moisture gradients, however, and may overestimate robust woody vegetation such as chaparral and woodland cover relative to that of the scrub and grassland assemblages. Historical ecologists likely would need to follow an iterative process (Grossinger et al. 2008) that uses (1) historical sources (e.g., 18th century Spanish explorers' journals, 19th century photographs), (2) current information from soil maps and plant life history data (e.g., Pavlik et al. 1993, Sawyer and Keeler-Wolf 1995), and (3) rainfall and fog moisture inputs for the island (Fischer and Still 2007, Baguskas et al. 2016). Historical research would also involve an extensive literature review to estimate the hectares of wood used for building materials and fuel, as well as the area of vegetation consumed annually by livestock throughout the 19th and 20th centuries. Detailed, decadal stocking records exist for the island (e.g., Collins 2009). Source intercalibration (Swetnam et al. 1999, Grossinger 2005, Whipple et al. 2011) provides a method for ranking and integrating data sets composed of information from different time periods, social contexts, and authors. Genetic comparative analysis of ancient and modern pollen to verify paleoecological models (Parducci et al. 2005) could be used to accomplish some of the above priorities.

Advances in molecular analytical methods have redefined our understanding of evolution in some species (e.g., island fox) using specimens collected decades ago, often changing our understanding in ways that may have been unimaginable to those who gathered and preserved the specimens (Hofman et al. 2015, Hykin et al. 2015). Care must be taken in using limited resources, especially if proposed analyses will destroy morphological features or deplete the original source material (e.g., limited stored quantities of blood or tissue). We therefore recommend that specimen 
owners require potential researchers to submit an application for biological sample use so that the suite of hypotheses to be evaluated and the conservation relevance of the research is reviewed prior to sample use and destruction. Similarly, sample owners should consider setting aside well-preserved samples to ensure that historic samples are available to future scientists.

\section{Documenting the Present}

Future researchers and conservationists will benefit from systematic surveys and specimen collections that document the island's faunal conditions in the 21st century, including information about relative rarity and local adaptation of endemic populations. We identified 6 priorities for data collection. First, we recommend that animal monitoring efforts be expanded from annual surveys of landbirds (Coonan et al. 2011) to include other species groups amendable to systematic counts, such as butterflies, lizards, frogs, and bats. Second, we encourage continuing and extending demographic studies of endemic vertebrates that serve as keystone species or ecological indicators, such as Island Scrub-Jays (Caldwell et al. 2013), island foxes (Bakker et al. 2009), spotted skunks, Channel Islands slender salamanders (Batrachoseps pacificus), and island fence lizards (Sceloporus occidentalis becki). Third, we agreed on the importance of periodic photographic monitoring of both historically photographed points (Beltran et al. 2014) and restoration sites such as the Prisoners Harbor wetland (NPS 2010). Fourth, we need to initiate routine collection of islandwide temperature and humidity data at an ecologically relevant spatial scale (Sofaer et al. 2017). Fifth, we highlight the need to identify temporal, spatial, demographic, and taxonomic gaps in specimen collections; to prioritize new collections of underrepresented taxa; and to collect modern series of key island taxa. Finally, standardized phenological data are needed for ecologically important species or communities, such as fruiting times of animal food plants like toyon (Heteromeles arbutifolia) and manzanita (Arctostaphylos spp.), the emergence of insect pollinators, arrival times of migratory songbirds, and the calling of Pacific chorus frogs (Pseudacris regilla). Phenological changes on the island have already been documented (Burkle et al. 2013, Van Vuren 2013) and are likely to increase in the coming decades (Randall et al. 2018). We recommend that the data collection outlined here be conducted in all of Santa Cruz Island's major terrestrial biomes.

The endemic fauna of Santa Cruz Island's grasslands and open scrublands were a focus of discussion at our workshop. The removal of introduced ungulates promoted recovery of coastal sage-scrub and chaparral ecosystems, but native populations of many grassland and open scrubland animals have declined over the past 30 years, including the Loggerhead Shrike (Lanius ludovicianus anthonyi; Stanley et al. 2012), Horned Lark (Eremophila alpestris insularis; Fancy 2000, Dye and Coonan 2015), and spotted skunk (Coonan 2015). Species that prefer open habitats may have experienced increases in abundance during the ranching era, making their recent declines partly attributable to habitat loss. Nevertheless, some of these declining populations existed prior to the clearing of native vegetation during European settlement (Caballero and Ashley 2011) and may be adapted to insular environmental conditions (Rick et al. 2014). A challenge facing biologists is how to manage all natives on Santa Cruz and the other California Channel Islands in the absence of livestock ranching and vegetation burning by indigenous human populations, activities that created and maintained island grasslands and scrublands (Carroll et al. 1993, Anderson et al. 2010). A key question is whether managers should create more open habitat (e.g., Eliason and Allen 1997), recognizing that this may involve trade-offs in other habitat and species recovery goals. Modeling the preranching ecosystem conditions of Santa Cruz Island, as described in "Documenting the Past," would provide a baseline for managing open habitats over the next century.

Systematic documentation of Santa Cruz Island's current faunal conditions will also establish a baseline for future understanding of the ecological effects of ongoing, rapid climate change. Until recently the influence of climate change on faunal turnover and shifts in species distributions was modeled using best estimates of past conditions but limiting our inferences to changes occurring over centuries (Koch and Barnosky 2006, Sandweiss and Kelley 2012, d'Alpoim Guedes et al. 2016). 
The rapid pace of contemporary climate change will impact animal assemblages over decadal time scales. Indeed, the 2012-2016 drought in California provided a glimpse of what may be the "new normal" (Wang et al. 2017, Fewings 2017, Swain et al. 2017).

Uncertainty about the effects of climate change emphasizes the importance of hypothesis-driven adaptive monitoring (Nichols and Williams 2006, Lindenmayer and Likens 2009) of Santa Cruz Island's terrestrial fauna. For example, ongoing research is testing whether the extent of oak chaparral and woodland is facilitated by long-distance acorn dispersal by Island Scrub-Jays (Sillett et al. 2012, Morrison 2014, Pesendorfer et al. 2017). Rapid recovery of oaks to their preranching range is predicted to enhance this ecosystem's climate change resilience by increasing population sizes of constituent species, restoring ecological interactions, and expanding the surface area of vegetation available for fog moisture capture. Testing these predictions will require measurement of fine-scale climate variation, monitoring of animal and plant populations, demographic studies of focal species, and field experiments to quantify oak recruitment. Research objectives will be adapted based on periodic statistical modeling of field data and assessments of experimental outcomes. Similar research that tests hypotheses about the island's ecological processes and is designed to accommodate environmental and sampling uncertainty would greatly enhance the future value of our monitoring data sets. Moreover, the usefulness of faunal studies on Santa Cruz Island will be maximized if they are embedded within broader research programs involving other Channel Islands and the adjacent mainland (Morrison et al. 2014).

\section{LOOKING TO THE FUTURE}

Our workshop included scientists and resource managers in various stages of their careers, which served to underscore the role that all can play as contributors to the historical legacy of a place. By putting ourselves in the shoes of future scientists and practitioners, we sought to identify information and materials pertaining to past and present conditions that might well become invaluable to future conservation management. In that light, we identified research questions that could not only lead to important contemporary discoveries but also motivate sample collection that could benefit future historical ecologists focused on Santa Cruz Island:

- Is island species diversity in a dynamic equilibrium (Harmon and Harrison 2015)?

- Which island forms are ecologically or evolutionarily distinctive and thus should be managed as endemic taxa (Robertson et al. 2014)?

- Is the rate of faunal speciation increasing?

- When did extant wildlife diseases and pathogens arrive on the island?

- What are the pollinators of endemic plants?

- Has the residency status of potentially migratory bird, bat, and insect species changed?

- Which attributes allow competing island species to coexist and how do we manage for those attributes to maximize species persistence?

- How do we leverage knowledge of Santa Cruz Island to inform research and conservation on other islands?

- Are we doing what is necessary to preserve the ecological and cultural character of the island?

In conclusion, we hope that the results of our workshop will help build a framework for interdisciplinary study of Santa Cruz Island's terrestrial fauna that will drive a concerted research agenda for the decades ahead. Our central goals were to identify gaps in existing collections and to recommend priorities for filling those gaps and for assembling an archive of current faunal conditions. We echo the call to recognize the generational imperative we have at this moment of transformative global change to better document the past and present of this island system (Morrison et al. 2018).

\section{ACKNOWLEDGMENTS}

We thank the participants of the 2016 Island Rediscovery Workshop held 28-29 January 2016 at the Santa Barbara Museum of Natural History and sponsored by The Nature Conservancy and the Smithsonian Institution. We also thank the participants of a follow-up 
workshop held 3 October 2016 during the 9th California Islands Symposium in Ventura, California. This paper benefitted from comments by S. Morrison, J. Randall, and 2 anonymous reviewers.

\section{Literature Cited}

Anderson, R.S., S. Starratt, R.M.B. Jass, and N. Pinter. 2010. Fire and vegetation history on Santa Rosa Island, Channel Islands, and long term environmental change in southern California. Journal of Quaternary Science 25:782-797.

Baguskas, S.A., C.J. Still, D.T. Fischer, C.M. D’Antonio, AND J.Y. KING. 2016. Coastal fog during summer drought improves the water status of sapling trees more than adult trees in a California pine forest. Oecologia 181:137-148.

BaKker, V.J., D.F. DOAK, G.W. Roemer, D.K. Garcelon, T.J. Coonan, S.A. Morrison, C. Lynch, K. Ralls, AND R. SHAW. 2009. Incorporating ecological drivers and uncertainty into a demographic population viability analysis for the island fox. Ecological Monographs 79:77-108.

Beltran, R.S., N. Kreidler, D.H. Van Vuren, S.A. MorRison, E.S. ZaValeta, K. Newton, B.R. Tershy, AND D.A. Croll. 2014. Passive recovery of vegetation from herbivore eradication on Santa Cruz Island, California. Restoration Ecology 22:790-797.

Brodersen, J., and O. Seehausen. 2014. Why evolutionary biologists should get seriously involved in ecological monitoring and applied biodiversity assessment programs. Evolutionary Applications 7:968-983.

Brumbaugh, R.W. 1980. Recent geomorphic and vegetal dynamics on Santa Cruz Island, California. Pages 139-158 in D.M. Power, editor, The California islands: proceedings of a multidisciplinary symposium. Santa Barbara Museum of Natural History, Santa Barbara, CA

Burkle, L.A., J.C. Marlin, and T.M. Knight. 2013. Plant-pollinator interactions over 120 years: loss of species, co-occurrence, and function. Science 339: $1611-1615$.

Caballero, I., And M. Ashley. 2011. Genetic analysis of the endemic Island Loggerhead Shrike, Lanius ludovicianus anthonyi. Conservation Genetics 12: $1485-1493$.

Caldwell, L., V.J. Bakker, T.S. Sillett, M.A. Desrosiers, S.A. Morrison, ANd L.M. ANGELONI. 2013. Reproductive ecology of the Island Scrub-Jay. Condor 115:603-613.

Carroll, M.C., L.L. Laughrin, and A.C. Bromfield 1993. Fire on the California islands: does it play a role in chaparral and closed cone pine forest habitats? Pages 73-88 in F. Hochberg, editors, Third California Islands Symposium: recent advances in research on the California islands. Santa Barbara Museum of Natural History, Santa Barbara, CA.

Cayan, D.R., E.P. Maurer, M.D. Dettinger, M. Tyree, and K. Hayhoe. 2008. Climate change scenarios for the California region. Climatic Change 87: S21-S42

Chatzimanolis, S., and M.S. Caterino. 2011. Exploring the beetle biodiversity on the California Channel Islands: a final report to the National Geographic
Society's Committee for Research and Exploration. $18 \mathrm{pp}$.

Collins, P.W. 2009. Historic and prehistoric record for the occurrence of Island Scrub-Jays (Aphelocoma insularis) on the northern Channel Islands, Santa Barbara County, California. Santa Barbara Museum of Natural History Technical Reports No. 5, Santa Barbara, CA.

Collins, P.W., AND H.L. Jones. 2016. A checklist of birds of the California Channel Islands. Santa Barbara Museum of Natural History, Santa Barbara, CA.

CoOnan, T.J. 2015. Draft report of the seventeenth annual meeting, Island Fox Working Group. Report issued by the Institute for Wildlife Studies, Arcata, CA.

Coonan, T.J., L.C. Dye, and S.G. Fancy. 2011. Landbird monitoring protocol for Channel Islands National Park. Version 2.0. Natural Resources Report NPS/ MEDN/NRR-2011/480. National Park Service, Fort Collins, CO.

Coonan, T.J., C.A. Schwemm, and D.K. Garcelon. 2010. Decline and recovery of the island fox: a case study for population recovery. Cambridge University Press, New York, NY.

Cory, C., And J.J. Knapp. 2014. A program to eradicate twenty-four nonnative invasive plant species from Santa Cruz Island. Monographs of the Western North American Naturalist 7:455-464.

D’Alpoim Guedes, J.A., S.A. Crabtree, R.K. Bocinsky, AND T.A. KOHLER. 2016. Twenty-first century approaches to ancient problems: climate and society. Proceedings of the National Academy of Sciences 133:14483-14491.

Diffenbaugh, N.S., D.L. Swain, and D. Touma. 2015. Anthropogenic warming has increased drought risk in California. Proceedings of the National Academy of Sciences 112:3931-3936.

Dye, L.C., AND T.J. CoOnan. 2015. Landbird Monitoring 2014 Annual Report, Channel Islands National Park. Natural Resources Data Series. NPS/MEDN/NRDS2015-975, National Park Service, Fort Collins, CO.

Eliason, S.A., AND E.B. Allen. 1997. Exotic grass coemption in suppressing native shrubland re-establishment. Restoration Ecology 5:245-255.

Erlandson, J.M., T.C. Rick, T.J. Braje, M. Casperson, B. Culleton, B. Fulfrost, T. Garcia, D.A. Guthrie, N. Jew, and D.J. Kennett. 2011. Paleoindian seafaring, maritime technologies, and coastal foraging on California's Channel Islands. Science 331:1181-1185.

FANCY, S.G. 2000. Review of the Channel Islands National Park Landbird Monitoring Protocol. Unpublished report prepared for Channel Islands National Park, Ventura, CA.

FEwINGS, M.R. 2017. Large-scale structure in wind forcing over the California Current System in summer. Monthly Weather Review 145:4227-4247.

Fischer, D.T., AND C.J. STILL. 2007. Evaluating patterns of fog water deposition and isotopic composition on the California Channel Islands. Water Resources Research 43, no. 4

Grossinger, R.M. 2005. Documenting local landscape change: the San Francisco Bay Area Historical Ecology Project. Pages 425-442 in D. Egan and E.A. Howell, editors, The historical ecology handbook: a restorationist's guide to reference ecosystems. Island Press, Washington, DC.

Grossinger, R.M., E.E. Beller, M.N. Salomon, A.A Whipple, R.A. Askevold, C.J. Striplen, E. BrewSTER, AND R.A. LiEDy. 2008. South Santa Clara Valley 
historical ecology study: including Soap Lake, the Upper Pajaro River, and Llaga, Uvas-Carnadero, and Pacheco Creeks. San Francisco Estuary Institute, Oakland, CA.

Harmon, L.J., AND S. HaRrison. 2015. Species diversity is dynamic and unbounded at local and continental scales. American Naturalist 185:584-593.

Hayhoe, K., D. Cayan, C.B. Field, P.C. Frumhoff, E.P. Maurer, N.L. Miller, S.C. Moser, S.H. SchneIDer, K.N. Cahill, E.E. Cleland, et al. 2004. Emissions pathways, climate change, and impacts on California. Proceedings of the National Academy of Sciences 101:12422-12427.

Hofman, C.A., T.C. Rick, M.T.R. Hawkins, W.C. Funk, K. Ralls, C.L. Boser, P.W. Collins, T. Coonan, J.L. KING, S.A. MoRRISON, ET AL. 2015. Mitochondrial genomes suggest rapid evolution of dwarf California Channel Islands foxes (Urocyon littoralis). PLOS ONE 10:e0118240.

Holmes, M.W., T.T. Hammond, G.O.U. Wogan, R.E. Walsh, K. LaBarbera, E.A. Wommack, F.M. MarTINS, J.C. CRAWFORD, K.L. Mack, L.M. Bloch, and M.W. NAchman. 2016. Natural history collections as windows on evolutionary processes. Molecular Ecology 25:864-881.

Hykin S.M., K. BI, AND J.A. McGuire. 2015. Fixing formalin: a method to recover genomic-scale DNA sequence data from formalin-fixed museum specimens using high-throughput sequencing. PLOS ONE 10(10):e0141579.

Jackson, J.B., M.X. Kirby, W.H. Berger, K.A. BJomdal, L.W. Botsford, B.J. Bourque, R.H. Bradbury, R. Cooke, J. Erlandson, and J.A. Estes. 2001. Historical overfishing and the recent collapse of coastal ecosystems. Science 293:629-637.

KINDSVATER, L. 2006. Conservation and restoration of the endemic island oak, Quercus tomentella in Channel Islands National Park using a habitat approach. Doctoral dissertation, University of California, Davis, CA.

Klinger, R.C., P. Schuyler, and J.D. Sterner. 2002. The response of herbaceous vegetation and endemic plant species to the removal of feral sheep from Santa Cruz Island, California. Pages 141-154 in C.R. Veitch and M.N. Clout, editors, Turning the tide: the eradication of invasive species. IUCN SSC Invasive Species Specialist Group. IUCN, Gland, Switzerland, and Cambridge, United Kingdom.

Koch, P.L., AND A.D. BARNOSKY. 2006. Late Quaternary extinctions: state of the debate. Annual Review of Ecology, Evolution and Systematics 37:215-250.

Langin, K.M., T.S. Sillett, W.C. FunK, S.A. Morrison, M.A. Desrosiers, and C.K. Ghalambor. 2015. Islands within an island: repeated adaptive divergence in a single population. Evolution 69:653-665.

Lindenmayer, D.B., And G.E. Likens. 2009. Adaptive monitoring: a new paradigm for long-term research and monitoring. Trends in Ecology and Evolution 24:482-486.

Miller S.E. 1985. The California Channel Islands-past, present, and future: an entomological perspective. Pages 3-27 in A.S. Menke and D.R. Miller, editors, Entomology of the California Channel Islands: proceedings of the first symposium. Santa Barbara Museum of Natural History, Santa Barbara, CA.

Millien, V. 2006. Correction: morphological evolution is accelerated among island mammals. PLOS Biology 4:e384.
Morrison, S.A. 2011. Trophic considerations in eradicating multiple pests. Pages 208-212 in C.R. Veitch, M.N. Clout, and D.R. Towns, editors, Island invasives: eradication and management. IUCN SSC Invasive Species Specialist Group. IUCN, Gland, Switzerland, and Cambridge, United Kingdom.

Morrison, S.A. 2014. A bird in our hand: weighing uncertainty about the past against uncertainty about the future in Channel Islands National Park. George Wright Forum 31:77-93.

Morrison, S.A., K.A. Parker, P.W. Collins, W.C. Funk, AND T.S. Sillett. 2014. Reintroduction of historically extirpated taxa on the California Channel Islands. Monographs of the Western North American Naturalist 7:531-542.

Morrison, S.A., T.S. Sillett, W.C. FunK, C.K. GhalamBOR, AND T.C. RICK. 2017. Equipping the 22nd century historical ecologist. Trends in Ecology and Evolution 32:578-588.

Morrison, S.A., T.S. Sillett, W.C. Funk, C.K. GhalamBOR, AND T.C. Rick. 2018. California island rediscovery: building an archive to improve conservation today and equip the historical ecologist of tomorrow. Western North American Naturalist 78:837-851.

[NPS] National Park Service. 2010. Prisoners Harbor Coastal Wetland Restoration Plan. Channel Islands National Park, Ventura, CA.

[NPS] National Park Service. 2015. Channel Islands National Park Final General Management Plan/ Wilderness Study/Environmental Impact Statement. Ventura and Santa Barbara Counties, CA.

Nichols, J.D., AND B.K. Williams. 2006. Monitoring for conservation. Trends in Ecology and Evolution 21: 668-673.

Parducci, L., Y. Suyama, M. Lascoux, and K.D. BenNETT. 2005. Ancient DNA from pollen: a genetic record of population history of Scots pine. Molecular Ecology 14:2873-2882.

Pauly, D. 1995. Anecdotes and the shifting baseline syndrome of fisheries. Trends in Ecology and Evolution 10:430.

Pavlik, B.M., P.C. Muick, And S.G. Johnson. 1993. Oaks of California. Cachuma Press, Los Olivos, CA.

Pesendorfer, M.B., C.M. Baker, M. Stringer, E. McDonald-Madden, M. Bode, A.K. McEachern, S.A. Morrison, And T.S. Sillett. 2017. Oak habitat recovery on California's largest islands: scenarios for the role of corvid seed dispersal. Journal of Applied Ecology 55:1185-1194.

Pinter, N., AND W.D. Vestal. 2005. El Niño-driven landsliding and postgrazing vegetative recovery, Santa Cruz Island, California. Journal of Geophysical Research 110, no. F2.

PowelL, J.A. 1994. Biogeography of Lepidoptera on the California Channel Islands. Pages 449-464 in W.L. Halvorson and G.J. Maender, editors, The Fourth California Islands Symposium: update on the status of resources. Santa Barbara Museum of Natural History, Santa Barbara, CA.

Randall, J.M., K. McEachern, J. Knapp, P. Power, S. JunaK, K. Gill, D. KnapP, and M. Guilliams. 2018. Informing our successors: what botanical information for Santa Cruz Island will researchers and conservation managers in the century ahead need the most? Western North American Naturalist 78:888-901.

Rentz, D.C., AND D.B. Weissman. 1981. Faunal affinities, systematics, and bionomics of the Orthoptera of the 
California Channel Islands. University of California Press, Oakland, CA.

Rick, T.C., T.J. Braje, J.M. Erlandson, K.M. Gill, L. Kirn, and L. MCLaren-Dewey. 2018. Horizon scanning: survey and research priorities for cultural, historical, and paleobiological resources of Santa Cruz Island, California. Western North American Naturalist 78:852-863.

Rick, T.C., C.A. Hofman, T.J. Braje, J.E. Maldonado, T.S. Sillett, K. Danchisko, and J.M. Erlandson. 2012. Flightless ducks, giant mice and pygmy mammoths: Late Quaternary extinctions on California's Channel Islands. World Archaeology 44:3-20.

RICK, T.C., AND R. LockWOOD. 2013. Integrating paleobiology, archeology, and history to inform biological conservation. Conservation Biology 27:45-54.

Rick, T.C., T.S. Sillett, C.K. Ghalambor, C.A. Hofman, K. Ralls, R.S. Anderson, C.L. Boser, T.J. Braje, D.R. Cayan, R.T. Chesser, et AL. 2014. Ecological change on California's Channel Islands from the Pleistocene to the Anthropocene. BioScience 64: $680-692$

Robertson, J.M., K.M. Langin, T.S. Sillett, S.A. MorriSon, C.K. Ghalambor, and W.C. FunK. 2014. Identifying evolutionarily significant units and prioritizing populations for management on islands. Monographs of the Western North American Naturalist 7:397-411.

[SDNHM] San Diego Natural History Museum. 2012. Taxonomic inventory of research and collection on Santa Cruz Island, California. Page 90 in K. Clark, editor, Internal report prepared for The Nature Conservancy. SDNHM, San Diego, CA.

SANDWEISS, D.H., AND A.R. KELLEy. 2012. Archaeological contributions to climate change research: the archaeological record as a paleoclimatic and paleoenvironmental archive. Annual Review of Anthropology 41:371-391.

Sawyer, J.O., and T. Keeler-Wolf. 1995. A manual of California vegetation. California Native Plant Society, Sacramento, CA.

Schoenherr, A.A., C.R. Feldmeth, and M.J. Emerson. 1999. Natural history of the islands of California. University of California Press, Berkeley, CA

Sillett, T.S., R.B. Chandler, J.A. Royle, M. Kery, AND S.A. Morrison. 2012. Hierarchical distance- sampling models to estimate population size and habitat-specific abundance of an island endemic. Ecological Applications 22:1997-2006.

Sofaer, H.R., J.J. Barsugli, C.S. Jarnevich, J.T. Abatzoglou, M.K. Talbert, B.W. Miller, and J.T. Morisette. 2017. Designing ecological climate change impact assessments to reflect key climatic drivers. Global Change Biology 23:2537-2553.

Stanley, T.R., S. Teel, L.S. Hall, L.C. Dye, and L.L. Laughrin. 2012. Population size of Island Loggerhead Shrikes on Santa Rosa and Santa Cruz Islands. Wildlife Society Bulletin 36:61-69.

Suarez, A.V., And N.D. Tsutsui. 2004. The value of museum collections for research and society. BioScience 54:66-74.

Swain, D.L., D. Singh, D.E. Horton, J.S. Mankin, T.C. Ballard, and N.S. Diffenbaugh. 2017. Remote linkages to anomalous winter atmospheric ridging over the northeastern Pacific. Journal of Geophysical Research: Atmospheres 122, no. 22.

Swetnam, T.W., C.D. Allen, and J.L. Betancourt. 1999. Applied historical ecology: using the past to manage for the future. Ecological Applications 9:1189-1206.

SzABó, P. 2015. Historical ecology: past, present and future. Biological Reviews 90:997-1014.

VAn Vuren, D.H. 2013. Avian response to removal of feral sheep on Santa Cruz Island, California. Wilson Journal of Ornithology 125:134-139.

VAN VuREN, D.H., AND V.J. BAKKER. 2009. Rapid morphological change in an insular population of feral sheep. Journal of Zoology 277:221-231.

Wang, S.Y., J. Yoon, R.R. Gillies, and H.H. Hsu. 2017. The California Drought. Pages 223-235 in Climate extremes: patterns and mechanisms. John Wiley \& Sons, Inc.

Whipple, A.A., R.M. Grossinger, and F.W. Davis. 2011. Shifting baselines in a California oak savanna: nineteenth century data to inform restoration scenarios. Restoration Ecology 19:88-101.

Received 5 May 2017 Revised 5 March 2018 Accepted 28 June 2018

Published online 23 October 2018 